\title{
Property Rights in Space: Moving the Goal Posts so the Players don't Notice
}

\author{
W Erlank*
}

\section{P.E.R}

Pioneer in peer-reviewed, open access online law publications.

Author

Wian Erlank

Affiliation

North-West University,

South Africa

Email Wian.Erlank@nwu.ac.za

Date published

16 November 2016

Editor Prof S du Toit

How to cite this article

Erlank W "Property Rights in Space: Moving the Goal Posts so the Players don't Notice" PER / PELJ 2016(19) - DOI http://dx.doi.org/10.17159/17273781/2016/v19i0a1505

\section{Copyright}

DOI

http://dx.doi.org/10.17159/17273781/2016/v19i0a1505

\begin{abstract}
Elsewhere in "Rethinking Terra Nullius and Property in Space", I have argued that due to the changing circumstances of access to space by private entities rather than governments, the current legal situation with regard to ownership in space should be reconsidered. As it stands, ownership in space is governed by international law and currently private and even national ownership of celestial bodies is prohibited.
\end{abstract}

While (controversially) arguing for the recognition of private ownership in space, I constantly have to field questions surrounding the pragmatic assertion that since international law and United Nations treaties and conventions prohibit ownership in space, there can be no development that will allow for this. Hence, while not abandoning my purely property law-oriented arguments for recognising private ownership in and on celestial bodies, I will maintain my arguments for property rights in space and analyse a number of differing options available to private entities who would like to acquire property rights in space. As such, I purposefully avoid the maligned terminology of "ownership", and rather look at various other options that still give the intrepid celestial entrepreneur some sort of property right, or even a property-like protection of their interests in space. Some examples include concessions, mining licences, prospecting rights, and certain contractual rights that could benefit from property-like protection.

The thesis is that even if ownership of celestial objects is not accepted due to the existence of various problematic dogmatic viewpoints, one would still be able to achieve much the same effect by using other property mechanisms.

\section{Keywords}

space law; space; outer space; ownership; moon; mars; property rights in space; property law; property-like rights; Outer Space Treaty; Moon Treaty; appropriation; non-appropriation principle; mining; tourism; colonisation. 


\section{Introduction}

Ladies and gentlemen, interested parties and academics; who owns the Moon? ${ }^{1}$ Who owns Mars, Halley's Comet or the rings around Saturn? This might seem like a relatively straightforward question. However, the answer is not quite as clear-cut as it may seem at first glance. As with the meaning of "property", 2 the answer will differ radically depending on whom you might ask. If you ask the man on the street, the answer might well be "no one", or you might very well be inundated with quirky tales about people buying parcels of land on the moon that was advertised next to the $\mathrm{x}$-ray specs, whoopee cushions and itching powder at the back of a comic book or on the internet. ${ }^{3}$ Some might even proudly produce a certificate to prove their "ownership". 4 If you ask a space lawyer "who owns the Moon?" he or she will, without hesitation, answer "no one". Because, they will tell you, the applicable United Nations Space Law conventions ${ }^{5}$ prohibit private ownership of any real estate in space. ${ }^{6}$ However, this does not

* Wian Erlank. HonsBA (Classical Literature) (Stell), LLB (Stell), LLM (International Trade Law) (Stell), LLD (Stell). Associate Professor in Law, Law Faculty, North-West University (Potchefstroom Campus). Advocate of the High Court of South Africa. Email: wian.erlank@nwu.ac.za. This article is based on a paper delivered at the Association of Law, Property and Society's (ALPS) Annual International conference held in Vancouver, Canada, 2014. The research for this article was finalised in the Netherlands, while the author was kindly being hosted by Prof JHM van Erp at the Maastricht University Faculty of Law.

1 Reynolds 2008 http://bit.ly/1qe0VO5; Marks NewScientist 28.

2 Erlank Property in Virtual Worlds.

3 Erlank 2012 http://bit.ly/24J1GhO; Erlank 2015 PELJ. The SSRN version of "Rethinking Terra Nullius and Property Law in Space" was initially presented at the Space and Law Forum held in Toulouse, France in 2012. The arguments raised in this paper have been developed and expanded in the final version, and will be published in PELJ 2015(4) under the same name. "Rethinking Terra Nullius and Property Law in Space" forms the first in a series on property law in space and precedes this article.

$4 \quad$ Erlank 2012 http://bit.ly/24J1GhO; Erlank 2015 PELJ.

5 Amongst others, the Treaty on Principles Governing the Activities of States in the Exploration and Use of Outer Space, including the Moon and Other Celestial Bodies (1967) (Outer Space Treaty) and the Agreement Governing the Activities of States on the Moon and Other Celestial Bodies (1979) (Moon Agreement).

$6 \quad$ Since the inception and the writing of this article, the United States has signed into law the US Commercial Space Launch Competitiveness Act HR 2262 of 2015, aiming to enable and provide legal and sovereign support for the commercial exploration and use of space resources. This move by the United States will have a direct influence on the current position. Since it is too soon to do anything but speculate about the effect of this law, I will not address this further, but leave it for a later article. The fact that the United States has taken a position (which could be interpreted to go against the status quo) does seem to underscore the need for the current position to be re-assessed so that private ownership of space resources could become a reality in future. 
preclude ownership of (man-made) movables in space such as man-made satellites, moon buggies and rovers. ${ }^{7}$

Let us take a moment and quickly look at the applicable conventions. The five main treaties are the Treaty on Principles Governing the Activities of States in the Exploration and Use of Outer Space, including the Moon and Other Celestial Bodies (1967) (Outer Space Treaty), ${ }^{8}$ Agreement on the Rescue of Astronauts, the Return of Astronauts and the Return of Objects Launched into Outer Space (1968) (Rescue Agreement); ${ }^{9}$ Convention on International Liability for Damage Caused by Space Objects (1972) (Liability Convention); ${ }^{10}$ Convention on Registration of Objects Launched into Outer Space (1975); ${ }^{11}$ and the Agreement Governing the Activities of States on the Moon and Other Celestial Bodies (1979) (Moon Agreement). ${ }^{12}$ These were all drafted by the United Nations Committee on the Peaceful Uses of Outer Space (UNCOPUOS).

Of these conventions the most pertinent when it comes to dealing with the issues of ownership or the lack thereof can be gleaned from articles I and II of the Outer Space Treaty, as well as articles 11(2) and 11(3) of the Moon Agreement. ${ }^{13}$ The following extracts from these articles highlight most clearly the position with regard to ownership.

7 Twibell 1997 ILSA J Int'I \& Comp L 268; Cherian and Abraham 2007 JICLT 213. This also logically follows from the fact that the Launching State always retains jurisdiction and control over all (man-made) objects for which they are responsible.

8 Treaty on Principles Governing the Activities of States in the Exploration and Use of Outer Space, including the Moon and Other Celestial Bodies (1967), hereafter referred to as the Outer Space Treaty.

9 Agreement on the Rescue of Astronauts, the Return of Astronauts and the Return of Objects Launched into Outer Space (1968), hereafter referred to as the Rescue Agreement.

10 Convention on International Liability for Damage Caused by Space Objects (1972), hereafter referred to as the Liability Convention.

11 Convention on Registration of Objects Launched into Outer Space (1975), hereafter referred to as the Registration Convention.

12 Agreement Governing the Activities of States on the Moon and Other Celestial Bodies (1979), hereafter referred to as the Moon Agreement.

13 The Moon Agreement is also often referred to as the Moon Treaty, and the two names can be used interchangeably. 
Article I of the Outer Space Treaty ${ }^{14}$ states that:

The exploration and use of outer space, including the Moon and other celestial bodies, shall be carried out for the benefit and in the interests of all countries, ... and shall be the province of all mankind ... there shall be free access to all areas of celestial bodies... ${ }^{15}$

The first two property aspects here do not create issues, since they denote a type of public trust (the province of all mankind) or vague general references to the fact that celestial bodies must be explored and exploited for public benefit as well as interest. These concepts do not necessarily prohibit private ownership. The third property focus here seems to be that outer space (and everything natural in it) should be regarded as a type of commons, although free access can also be regarded as an explicit curtailment of the right to exclude, while not negating other competencies of ownership such as the rights to exploit, use and enjoy.

Article II states that:

Outer space, including the Moon and other celestial bodies, is not subject to national appropriation by claim of sovereignty, by means of use or occupation, or by any other means. ${ }^{16}$

This article, however, explicitly puts celestial bodies and outer space in the category of res extra commercium ${ }^{17}$ (or property that falls outside the scope of commerce). It is interesting to note that by stating this explicitly, the convention is in fact underlining the fact that these celestial bodies are the objects of property law. This is also the article that is responsible for the so-called "non-appropriation principle". ${ }^{18}$

14 "The exploration and use of outer space, including the Moon and other celestial bodies, shall be carried out for the benefit and in the interests of all countries, irrespective of their degree of economic or scientific development, and shall be the province of all mankind. Outer space, including the Moon and other celestial bodies, shall be free for exploration and use by all States without discrimination of any kind, on a basis of equality and in accordance with international law, and there shall be free access to all areas of celestial bodies. There shall be freedom of scientific investigation in outer space, including the Moon and other celestial bodies, and States shall facilitate and encourage international cooperation in such investigation." Art I of the Outer Space Treaty.

15 Emphasis added.

16 Emphasis added.

17 See the discussion about the classification of things inside and outside of commerce as it relates to ownership in space. Erlank 2012 http://bit.ly/24J1GhO 6-12; Erlank 2015 PELJ.

18 See Freeland "Outer Space and the Non-Appropriation Principle" 85; Goh Dispute Settlement 18, 140; Van Wyk 2008 African Skies 90; Erlank 2012 http://bit.ly/24J1GhO 5; Erlank 2015 PELJ. 
No analysis is complete without a reference to the limp celery ineffectiveness of the Moon Agreement, ${ }^{19}$ which states that:

2. The Moon is not subject to national appropriation by any claim of sovereignty, by means of use or occupation, or by any other means.

3. Neither ... nor ... shall become property of any State, international intergovernmental or non-governmental organization, national organization or non-governmental entity or of any natural person ...20

This treaty therefore slightly expands on the prohibition of private ownership by states and includes a prohibition of private ownership by individuals. However, as said above, the Moon Agreement is for all intents and purposes regarded as an ineffective and failed treaty, since the convention has not been and is not being ratified by the main space-faring powers. ${ }^{21}$ As such, it is of only academic interest ${ }^{22}$ - and should not be an obstacle to recognising or regulating property rights in space. ${ }^{23}$

In "Rethinking terra nullius and property law in space"24 I argued that due to the changing circumstances of access to space by private ${ }^{25}$ entities rather than governments, the current legal situation with regard to ownership in space should be reconsidered. ${ }^{26}$ I further argue for the recognition of private ownership in space by making use of the basic tenets and dogmatic foundations of property law. ${ }^{27} \mathrm{I}$ do not, however, condone nor argue for the ability of anyone, nation or government to

19 "2. The Moon is not subject to national appropriation by any claim of sovereignty, by means of use or occupation, or by any other means. 3. Neither the surface nor the subsurface of the Moon, nor any part thereof or natural resources in place, shall become property of any State, international intergovernmental or non-governmental organization, national organization or non-governmental entity or of any natural person. The placement of personnel, space vehicles, equipment, facilities, stations and installations on or below the surface of the Moon, including structures connected with its surface or subsurface, shall not create a right of ownership over the surface or the subsurface of the Moon or any areas thereof. The foregoing provisions are without prejudice to the international regime referred to in paragraph 5 of this article." Moon Agreement Arts 11(2) and 11(3).

20 Emphasis added.

21 Listner 2003 Regent J Int'l L 85; Marks NewScientist 28; Reynolds 2008 http://bit.ly/1qe0VO5; Listner 2011 http://bit.ly/21TTN7n; Fuentes 2015 http://bit.ly/1OfvM8x; Erlank 2012 http://bit.ly/24J1GhO; Erlank 2015 PELJ.

22 Which will not be addressed in this paper.

23 Freeland 2010 Melb J Int'l L 103 fn 62; Erlank 2012 http://bit.ly/24J1GhO 4; Erlank 2015 PELJ. For an in-depth discussion of the Moon Agreement including support for it, see Hoffstadt 1994 UCLA L Rev 583, 585.

24 Erlank 2012 http://bit.ly/24J1GhO; Erlank 2015 PELJ.

25 Private, as opposed to Governmental or Nation State; hence here "private" will include both individuals as well as corporate entities. See Erlank 2012 http://bit.ly/24J1GhO 11, 13-14; Erlank 2015 PELJ.

26 Erlank 2012 http://bit.ly/24J1GhO 1, 15; Erlank 2015 PELJ.

27 Erlank 2012 http://bit.ly/24J1GhO 5, 12-13; Erlank 2015 PELJ. 
appropriate objects in outer space, including heavenly bodies, by means of so-called "flag planting". ${ }^{28}$ This is an important distinction to take note of, since my nuanced approach to the recognition of private property rights manages to make it essentially impossible for the "appropriation" of outer space bodies in such a way as to embody the fears and caveats that led to the current principle of non-appropriation. ${ }^{29}$

An unfortunate side effect of these arguments is that I constantly have to field questions about the pragmatic assertion that since international law (including United Nations Treaties and Conventions) prohibits ownership in space, there can be no development that will allow for this. ${ }^{30}$ Essentially the conversation goes something like this:

Erlank: Developments in space science, as well as practice have created a situation where we now need to acknowledge the need for private ownership in space and develop this concept by means of reference to (private) property law.

Space lawyer: Yes, it all sounds well and good, but you are wasting your time, since international law and the UN conventions prohibit private ownership in space. Are you not wasting your time with this?

Erlank: No, the law HAS to develop and adapt to the realities of developments in the real world. It is clear that the current legal situation is untenable, outdated, and must be changed.

Space Lawyer: I see, but it is still impossible to change, since it is already regulated by international law.

\section{Erlank: *feeling perplexed*}

The above dialogue comes very close to verbatim exchanges on a number of occasions and can be attributed to a number of different issues. The first is of course that many practising lawyers and even academics tend to

28 Nations are still making use of this practice to try to claim sovereignty over contested land, such as when Russia planted a flag on the sea bed under the North Pole in order to further their claims to the Arctic. See BBC News $2007 \mathrm{http}: / / \mathrm{bbc} . i n / 1$ XjQVAk.

29 For a cogent argument against the change of the non-appropriation principle, see Freeland "Outer Space and the Non-Appropriation Principle". As noted in the main text above, when taking into consideration my nuanced approach to the recognition of property rights, I believe that rather than the arguments being contra to that of Freeland, they manage to develop the current system and strengthen the main aims of the non-appropriation principle (preventing the large-scale ineffective exclusionary appropriation of heavenly bodies without being able to make effective use of or exert physical control over it), while still managing to allow for both economic, technological and scientific development. See in general Erlank 2016 (forthcoming); and Erlank 2012 http://bit.ly/24J1GhO; Erlank 2015 PELJ. But see Blount 2011 Denv J Int'l L \& Pol'y. 
view law through positivist glasses as a fixed and stagnant system, which it is not. ${ }^{31} \mathrm{I}$ am a firm believer in the constant development of the law, and the short answer to these questions is quite simply that the conventions have become irrelevant in this age and must change. However, to appease the international and space lawyers who are content with the certainty provided by the status quo I will make use of a bit of legal illusion to still develop space law (in an acceptable manner).

So let's move the goalposts so that the players do not notice. I will refrain from using the much maligned and contested word ownership, as well as the associated "appropriation" mentioned earlier, since clearly this is what creates all the problems.

\section{$2 \quad$ Mining, tourism and construction in space}

\subsection{Introduction}

As an illustration of the concept of how space-related ${ }^{32}$ economic activity, investment, development and the eventual wealth-creation ${ }^{33}$ can influence one another and eventually property in space, two semi-related initiatives relating to property in space will be discussed. I will start by looking at mining operations and then move on to space tourism. It will be shown that the two initiatives complement each other, and that by using property rights, or at least using property-like rights to reward investment and innovation in space industries as a means of protecting such investment, these initiatives could form the basis of much broader developments in space - which are almost incidental to the initial economic incentive of the initiatives.

31 See Blount 2011 Denv J Int'l L \& Pol'y, who describes the current space-law regime in terms of architecture - outdated architecture that needs to change.

32 As a matter of interest, one of the big debates in space-law concerns where exactly the limits between air-space and outer-space is located. The most generally accepted description comes from customary international law and refers to the boundary as 100 kilometres above sea level, it also refers to the so-called (Von) Kármán line. Hence, activities that take place beyond that line can be considered to be outer-space activities. Ferreira-Snyman 2014 PELJ 10, 10 fn 57, fn 58; Neger and Walter "Space Law" 240; Lyall and Larsen Space Law 167-168; DiederiksVerschoor Introduction to Space Law 15, 17.

33 Throughout this paper, "wealth" includes not only financial wealth, but also technological and social development as objects of wealth. 


\subsection{Mining and beneficiation in space}

Consider for a moment the following (non-fictional) property scenario. Companies such as Planetary Resources ${ }^{34}$ and Deep Space Industries ${ }^{35}$ are in the advanced stages of preparation to mine asteroids.

Planetary Resources ${ }^{36}$ plans to mine rare minerals including gold and platinum by initially locating and identifying near-Earth asteroids. ${ }^{37}$ Their initial estimates suggest that there are approximately 150 good targets, and as a first step telescopes will be launched into outer space to identify suitable candidates for mining. ${ }^{38}$ These are expected to launch in 2016. ${ }^{39}$ Planetary Resources plans to start mining operations within five to ten years (of 2012)..$^{40}$ Apart from the mining itself, they plan to build a fuel station in space to be used to refuel satellites and space ships, for instance. They also plan to mine water, since water from asteroids can be broken down into liquid oxygen and liquid hydrogen that can be used to produce rocket fuel. They will make use of robots and robot technology to do the mining, manufacture the fuel, and refuel the visiting space-craft. ${ }^{41}$

Deep Space Industries (DSI) prioritises the finding and mining of hydrogen and oxygen to refuel rockets. ${ }^{42}$ They will launch exploration satellites early in 2016 called FireFlies. In 2017 they plan to launch larger space-craft on two- to three-year missions to land on asteroids and obtain samples. Eventually, in 2019, they plan to launch a "harvester" space-craft to capture and divert promising asteroids into orbit around the Earth by 2021.43

34 Planetary Resources 2014 http://bit.ly/1sdM2gT.

35 DSI 2015 http://bit.ly/1XjRmdT.

36 Planetary Resources has some high profile names and deep pockets associated with it. It was founded by amongst others Larry Page (Creator of Google), Richard Branson (founder of the Virgin brand and explorer) and James Cameron (filmmaker and explorer). Planet Science 2012 http://bit.ly/23HPDyK; Thomas 2013 http://reut.rs/1XIrAGj.

37 Planet Science $2012 \mathrm{http} / / / \mathrm{bit} . l \mathrm{ly} / 23 \mathrm{HPDyK}$.

38 Planet Science $2012 \mathrm{http}: / /$ bit.ly/23HPDyK.

39 Thomas $2013 \mathrm{http}: / /$ reut.rs/1XIrAGj.

40 Planet Science $2012 \mathrm{http} / / / \mathrm{bit} . l \mathrm{l} / 23 \mathrm{HPDyK}$.

41 Planet Science 2012 http://bit.ly/23HPDyK.

42 Thomas $2013 \mathrm{http}: / /$ reut.rs/1XIrAGj.

43 There are numerous questions about the risks of diverting asteroids to an orbit around the Earth. The most obvious one is what if something goes wrong and the asteroid damages other orbiting objects. It would be more spectacularly problematic if the asteroid does not go into orbit, but in fact collides with the Earth. While technology at the moment and in the immediate future will allow only very small asteroids to be redirected like this, in theory a cataclysmic event could occur if a large enough asteroid were to strike the Earth. The question then is whether it is ethically and morally a good idea to invest in this type of technology. Would it not be 
The first aspect of mining in space that is usually mentioned in literature, and especially in the popular media, is that asteroids contain precious metals such as platinum, gold, rhodium, iridium, rhenium, osmium, ruthenium, palladium, and germanium, which have been found in meteorites and will therefore also be found in asteroids. ${ }^{44}$ Iron ore is also expected to be extremely bountiful. ${ }^{45}$ This is of interest to mining companies not only because the metals and other minerals are present on the asteroids, but because they are present in extremely high concentrations. For example, Planetary Resources estimates that platinum-rich asteroids 500 meters across could contain more than the total known reserves of platinum on Earth; and a $200 \mathrm{~km}$ wide Asteroid, 16 Psyche, from the asteroid belt between Mars and Jupiter, is estimated to contain enough nickel-iron ore to satisfy demand for millions of years. ${ }^{46}$ Even small asteroids could meet the demand for such metals for centuries. Questions have been raised (and answered) ${ }^{47}$ about the commercial viability of such space-mining operations, ${ }^{48}$ since the number of platinum ore-bearing near-Earth asteroids has been estimated by Elvis (using an impressive mathematical formula) to be $10 .{ }^{49}$ However, the number of asteroids containing water is a much more impressive $9000 .{ }^{50}$ Elvis also notes that "... the knowledge of which NEOs are ore-bearing could itself become commercially valuable intellectual property". ${ }^{51}$ This astute observation raises some rather difficult questions about the nonappropriation principle and if this principle should extent to such intellectual property.

Since the cost of bringing mined materials down to Earth would be prohibitive, the eventual use of the materials would be focussed on interplanetary refuelling stations and outer space construction endeavours, such as providing support for the building and fuelling of colonies on Mars. ${ }^{52}$ It follows that the real value is in further space travel and related activities, therefore making hydrogen and oxygen reserves equally

ironic if we had to evacuate the Earth because we caused an asteroid-related extinction event by our ventures into space mining. For more on capturing nearEarth Asteroids, see Hasnain, Lamb and Ross 2012 Acta Astronautica.

44 Thomas $2013 \mathrm{http}: / /$ reut.rs/1XIrAGj.

45 Thomas $2013 \mathrm{http}: / /$ reut.rs/1XIrAGj.

46 Thomas $2013 \mathrm{http}: / /$ reut.rs/1XIrAGj.

47 Sonter 1998 Acta Astronautica.

48 Komnenic $2014 \mathrm{http}: / /$ bit.ly/1ZCi7ch.

49 Elvis 2014 Planetary and Space Science 23.

$50 \quad$ Elvis 2014 Planetary and Space Science 24.

51 Elvis 2014 Planetary and Space Science 26.

52 Thomas $2013 \mathrm{http}: / /$ reut.rs/1XIrAGj. 
attractive for mining operations. ${ }^{53}$ This could result in the creation of space-factories that manufacture fuel for long-range interplanetary missions, as well as to extend the operating life of satellites by refuelling ${ }^{54}$ them. ${ }^{55}$ The leftover material from the mining and manufacturing process could be used for (radiation) shielding, building materials and concrete. ${ }^{56}$ Blair $^{57}$ notes in reference to discussions about settlements on Mars that

[t] he reason asteroid mining makes sense is because people might be some day where those resources are. You can't put an 80,000-person colony on Mars without using the local "timber". ${ }^{5}$

Since the author began the research for this article a number of substantive developments have taken place that indicate that the possibility of such mining expeditions is coming closer to realisation every day. Things have developed a lot since Skylab was launched into orbit in 1983. Skylab was built mainly by (West) Germany, Italy and France with the intention (amongst others) to investigate if products and objects manufactured and created in space could perform better than their Earthly counterparts. ${ }^{59}$ In 1984 a conference was held to review the preliminary results as well as to discuss the possibilities of "space factories", where the focus at the time was on manufacture in space for use on Earth. Now more than 30 years later the tide has changed to focus on manufacture in space for use in space, although the concept is not a new ${ }^{60}$ one.

Take for example the 2014 feat of the ESA ${ }^{61} /$ NASA Rosetta Mission, where we (as people) not only managed to successfully intercept a comet and keep up with it, but also managed to successfully send down a lander to the surface of the comet. ${ }^{62}$

Another impressive development is the proposed NASA/DSI Asteroid Redirect Mission, where the goal is to "catch" an asteroid and bring it back to Earth. ${ }^{63}$

\footnotetext{
53 Thomas $2013 \mathrm{http}: / /$ reut.rs/1XIrAGj.

54 Satellite propellant is a multi-billion dollar industry. Thomas 2013 http://reut.rs/1XIrAGj._At the moment, for most LEO (Low Earth Orbit) satellites, when the satellite's fuel runs out it inevitably goes into a decaying orbit and eventually re-enters the atmosphere and burns up.

55 Thomas $2013 \mathrm{http}: / /$ reut.rs/1XIrAGj.

56 Thomas $2013 \mathrm{http}: / /$ reut.rs/1XIrAGj.

57 Brad Blair is a mining engineer and economist.

58 Thomas $2013 \mathrm{http}: / /$ reut.rs/1XIrAGj.

59 Lewis $1984 \mathrm{http}: / /$ nyti.ms/1WmzfEz.

60 O'Leary 1988 Acta Astronautica.

61 European Space Agency (ESA).

62 See NASA JPL date unknown http://go.nasa.gov/27dZXDo; Risen 2014 http://bit.ly/21X2gqA; Hartnett 2014 http://bit.ly/2dUGd3u; ESA 2013 http://bit.ly/1rEZMjS; ESA 2015 http://bit.ly/1VSdOGN.

63 DSI date unknown http://bit.ly/24LnJld.
} 
NASA has also awarded funding to Tethers Unlimited Inc (TUI) to continue with their development of their SpiderFab technology. This technology will allow the manufacture of large-scale spacecraft components in space and avoid the cost of launching components from the Earth in rockets. ${ }^{64}$ The manufacturing will take place by using $3 \mathrm{D}$ printers and other additive manufacturing technologies like robotic assembly technologies to manufacture massive structures such as football-field sized antennas and telescopes. ${ }^{65}$ Eventually the technology could also be used to manufacture better and larger space-craft and other structures ${ }^{66}$ such as hotels. An architectural firm has also revealed that they are working on techniques that will allow the printing of habitable structures on the Moon (and presumably Mars). ${ }^{67}$ The plan is to use lunar soil68 as building material to construct a weight-bearing dome. Proof of the concept has already shown that this is a viable procedure.

\subsection{Tourist operations in space}

On another front, participants in the space-tourism ${ }^{69}$ arena face the same problems. Although space-tourism is still in its infancy, ${ }^{70}$ it is estimated that the number of space tourists could reach into the thousands of people within the next few years. ${ }^{71}$ As with other areas of space-related activities, it has been pointed out that the current outer space treaty regime is outdated and unable to deal with questions concerning the private use of space, especially in terms of space tourist activities. ${ }^{72}$ Ferreira-Snyman mentions $^{73}$ that

$[T]$ he possible space tourist activities include long-term stays in orbital facilities for research or entertainment purposes, short-term orbital or suborbital flights, and parabolic flights in aircraft where space tourists are exposed to weightless conditions.

To broadly mention some categories of space tourism, the first and most often talked about is the type that occurs in the so-called sub-orbital area

64 Brewster 2013 http://bit.ly/1Tzlixb; Dezeen 2013 http://bit.ly/1T9zfV6.

65 Dezeen 2013 http://bit.ly/1T9zfV6; Brewster 2013 http://bit.ly/1Tzlixb.

66 This is discussed in more detail below.

67 Foster and Partners 2013 http://bit.ly/1WYY8Fp; ESA 2013 http://bit.ly/1rEZMjS; Dezeen 2013 http://bit.ly/1T9zfV6.

68 Also known as "regolith".

69 Space tourism includes almost anything that has an interaction between customers, private citizens and space travel. Ferreira-Snyman 2014 PELJ 5.

70 Ferreira-Snyman 2014 PELJ 5.

71 See Ferreira-Snyman 2014 PELJ 5 fn 23; Sundahl 2009 J Space L 164; Freeland 2010 Melb J Int'l L 3.

72 Ferreira-Snyman 2014 PELJ 5.

73 Ferreira-Snyman 2014 PELJ 6; Hobe and Cloppenburg 2004 Proceedings of the IISL 377; Hobe 2007 Neb L Rev 439. 
of space flight, where the spacecraft does not achieve orbital velocity. ${ }^{74}$ Essentially, the tourism attraction here is that the space tourist or passenger will go up into outer space to experience the thrill of weightlessness, which usually lasts for three to six minutes at the utmost ${ }^{75}$ of an estimated 90 minute flight from start to finish.

A second category concerns intercontinental rocket transport, ${ }^{76}$ or making use of $\mathrm{ICBM}^{77}$ technology, to transport passengers much, much, much faster from point A to point B. ${ }^{78}$ An ICBM uses outer space for the purpose of considerably shortening normal travel time. In this case, the use of outer space is incidental to the tourist activity itself.

In a third category we find more interesting activities that do not purely relate to travel, such as for example an orbiting hotel, ${ }^{79}$ and beyond that, travel to a hotel on a heavenly body (such as the Moon, Mars, a comet, an asteroid, or even an outer space mining base). In this category one could also include the travel or exploration aspect of going to a space hotel as a type of tourist activity akin to going on a safari, where the journey, and not so much the destination, is the purpose of travel.

So how exactly does this relate to the development of and innovation of technology to go into outer space? Well, one could look at the initiative to go to Mars. At the moment any such operation would be too expensive for most individuals to finance, and this is why such initiatives tend to be focussing on crowd-funding and high profile supporters such as Elon Musk. ${ }^{80}$ Pioneers going on such a mission will pave the way for the tourist

74 Ferreira-Snyman 2014 PELJ 6.

75 Ferreira-Snyman 2014 PELJ 6.

76 Ferreira-Snyman 2014 PELJ 6-7.

77 Intercontinental ballistic missile (ICBM), but without the explosive payload. For purposes of this paper I use ICBM and Intercontinental Rocket interchangeably.

78 The rocket goes up, hangs around in outer space while the Earth turns underneath it, and then falls back down. This is therefore almost an up-down motion, instead of having to transverse the Earth under its own power. This is of course over simplified. For more accurate details about this procedure see Sippel 2010 Acta Astronautica 1652-1658; Dilorenzo and Hinnant 2013 http://yhoo.it/1XjRWZi; Orzel 2011 http://bit.ly/1qdZTlb; Wikipedia Contributors 2015 http://bit.ly/24OtSTS. As with many modern space-related technologies and applications, one can look towards the philosopher-science fiction authors; in this case, the concept of the use of ICBMs for faster and more effective travel is perfectly illustrated in Robert A Heinlein's Friday.

79 For more on the specifics of such orbiting hotels, including hotels in lunar orbit or located at the lunar poles see Ferreira-Snyman 2014 PELJ 5 fn 23; Walter "Privatisation and Commercialisation of Outer Space" 502; Freeland $2010 \mathrm{Melb} \mathrm{J}$ Int'l L 3 .

80 Crowd-sourced funding is employed by amongst others, the Mars-Initiative and Mars One. Mars Initiative 2015 http://www.marsinitiative.org; Mars One 2015 http://www.mars-one.com. 
industry. If the pioneers manage to a) get to Mars, b) survive there for a non-negligible time, c) lay the foundation for the building of a habitable environment which is hopefully self-sustaining and d) even if this should fail, the very fact that they did get there and arrived with some sort of provisions or building materials that could be used by a second batch of explorers when they get there would have immense implications. Eventually such a base-colony ${ }^{81}$ (if one could call it that) would also function as a type of tourist destination, or hotel, or at the very least a waypoint or resupply station where weary travellers could rest themselves. ${ }^{82}$ It is also not inconceivable that the very people who do manage to set up such a base station/colony would start to supply access to their facilities on a commercial basis. Payment for such accommodation would probably function more in terms of barter and trade in objects, rather than in terms of money. For example, you might be permitted to come and stay at the base station for a month or two if you brought with you essential articles for the operation, building and upkeep of the station and its permanent residents.

Alternatively to the categories identified above, one could also divide space-tourism activities into two distinct areas. The first one would be "tourism for the fun of it", which is essentially a relatively pointless exercise with nothing more to it than some sense of self-fulfilment, ${ }^{83}$ or edification. The second would be tourism with a specific goal that transcends tourism for fun. The difference could be described by making use of the analogy of a cruise ship going from point $A$ to point $B$, or even more specifically, a cruise from point $A$ to point $A$; which is also known as a "cruise to nowhere". If one were to take a pleasure cruise from Athens, Greece to Athens, Greece just for the purpose of enjoying the cruise itself, then it would fall into the first category. If, however, one were to make use of the pleasure cruise to move from point $A$ to point $B$, for the purpose of actually travelling to point B, (say from Athens, Greece to Istanbul, Turkey) then

81 The question about whose colony it will be remains unanswered. The concept of a colony presupposes an attachment to a sovereign nation. Will this be the first instance of a human colony unrelated to an existing sovereign state on Earth? Will this then also translate into the founding of a new sovereign territory of Martians? The fact that the Mars One initiative will initially be a one-way trip could allow for this development. However, this would be the ultimate form of appropriating property in space, and as such current conventions do not provide an answer.

82 Also see O'Leary 1988 Acta Astronautica 462. Apart from relying on the colonists to make do with what they take with them, prior un-manned missions to pre-supply essentials would improve the odds of success.

83 This in itself is not completely pointless, since the value of property and the economic activities relating to this is often based on the aims of self-fulfillment and human endeavour. See Radin Reinterpreting Property 5; Erlank Property in Virtual Worlds 141, 171-175. 
the tourism aspect would be incidental and the journey would be productive. Alternatively one could travel from point $A$ to point $B$ on a ship like the QE2,84 which is an ocean liner ${ }^{85}$ where the luxurious surroundings for the passengers are incidental to the purpose of getting the passenger from one place to another. On the other hand, a plain pleasure cruise by itself just has the purpose of providing entertainment.

So to translate this to space, the use of a rocket to go from point $A$ to point $\mathrm{B},{ }^{86}$ independently of how luxurious the rocket was, would be a functional use of tourism. ${ }^{87}$ If one were to go on a tourist flight just to experience weightlessness, then that would be non-functional.

Ferreira-Snyman argues ${ }^{88}$ that private human spaceflight is regarded as a mostly recreational activity, and due to the high cost associated with it it will in the near future be reserved for the wealthy space-travel enthusiast. She therefore questions how this could be of benefit to mankind in general. She answers her question by noting that space-tourism will most probably lead to more affordable access ${ }^{89}$ to space, which could be seen as being beneficial to all of mankind. ${ }^{90}$ She also notes that private human space flight might have certain social and economic advantages, including the development of new technologies ${ }^{91}$ in the area of human space travel, and may boost private investment, which would eventually inevitably

84 Queen Elizabeth 2 (the ocean liner).

85 Perhaps the difference between an ocean liner and a pleasure cruise ship (as well as their respective purposes) could be illustrated with reference to the first officer of the Britannia in Preston and Child Wheel of Darkness 80: "But Mrs. Dahlberg, I have to correct one thing you said: we're not a cruise ship. We're an ocean liner." "I didn't know there was a difference." "A world of difference! The point of a cruise ship is the cruise itself. But an ocean liner's job is to transport people on a schedule ... You see, a cruise ship will run away from a storm. We don't divert-we just plough right through."

86 Earth to Moon, or alternatively using an intercontinental rocket for faster transport from New York to Sydney, for example.

87 This could of course also be referred to as just "transport", but for the sake of the argument made above, this highlights the fact that the tourism industry could have other outcomes such as boosting or improving the way in which one deals with traditional transport.

88 Ferreira-Snyman 2014 PELJ 7.

89 This is not unlike the development and adoption of new computer and related technologies. As a new technology is created, it is initially available in very limited quantities to a small group of very rich/dedicated customers. The product, which initially is exclusive and limited in its wider impact, soon gets converted into better economies of scale and becomes the default standard for even the most mundane and cheapest consumer equipment. Think, for example, about the rise of the touchscreen smart-phone. While initially exorbitantly expensive, it is now so ubiquitous that the technology is even incorporated into so-called burner/disposable phones.

$90 \quad$ Ferreira-Snyman 2014 PELJ 7; Masson-Zwaan 2008 Proceedings of the IISL 536.

91 See the discussion in fn above. 
alleviate pressure on the expenditure of public funds for near-Earth space exploration. ${ }^{92}$ This of course follows the same ratio as that of commercial and mining activities in outer space, as discussed above. Ferreira-Snyman notes $^{93}$ that private entities do not need prior permission from any sovereign state to conduct tourist activities in outer space, although they do need authorisation from the launching state, which also has the obligation to continue to supervise the activities of that private entity. ${ }^{94}$ This is reasonable, since the launching state is itself responsible for any liability ${ }^{95}$ that arises from the actions of the private entity. ${ }^{96}$ The position of mining operations will remain unclear until more certainty about the property issues relating to mining has been developed.

In the end this boils down to the fact that the tourism as well as the mining industries itself can aid science, exploration and the development of man's general use of space. Let's take the example of building an orbiting hotel. It has been shown from the example of the building of the International Space Station (ISS) that this is a lengthy and long-term project. The main problem with this protracted exercise is that all construction material has to be manufactured on Earth and then blasted into outer space. This is exceptionally prohibitive, not only from a cost perspective but also from the perspective of the limitation on the prefabricated size of the components and materials that can be lifted into outer space. ${ }^{97}$ Therefore, if a blooming tourist industry in outer space is envisaged and there are enough private people willing and able to pay, even if just for the fun of it, for a ticket to an orbiting space station or even to the Moon, then of course the building of such a space station or Moon base will be profitable in the first place and

92 Ferreira-Snyman 2014 PELJ 8; Chatzipanagiotis 2011 Proceedings of the IISL 56.

93 Ferreira-Snyman 2014 PELJ 9.

94 Ferreira-Snyman 2014 PELJ 10.

95 For more on the issues of liability see Listner 2003 Regent $J$ Int'l L 80, 83-84; Ferreira-Snyman 2014 PELJ 28-38.

96 What is not mentioned here is the problem of launches from international waters, for example, where there is no launching state. In such a case it is possible that a private entity could launch a spacecraft or satellite into space without any sovereign territory being responsible for liabilities associated with this or in a position to supervise or regulate the associated activities.

97 In 2002 the average estimated cost of transporting one pound of mass into outer space was between $\$ 2000$ and $\$ 8500$ for LEO (Low Earth Orbit) and between $\$ 7000$ and $\$ 18900$ for GTO (Geostationary Transfer Orbit). Costs vary drastically, depending on the class of vehicle (small, medium/intermediate or heavy) and the question of whether a Western (US or European) or Eastern (Chinese, Russian and Ukrainian) launch vehicle was used. The Eastern launches were much cheaper. See Futron http://www.futron.com/upload/wysiwyg/Resources/Whitepapers/Space_Transportatio n_Costs_Trends_0902.pdf (on file with author). 
in the second, possible - since it makes use of a type of crowd-funding to cover the costs.

This nascent space-tourism industry, together with the pioneering drive for visits to Mars and other novel celestial real estate, will directly influence the technology as well as its applicability and the need for activities like the mining of asteroids and minerals in space. If one were able to get the base materials in outer space and had no need to lift them up from the Earth, then one would be able to use an orbiting factory to produce any required material in outer space, which would have a positive knock-on effect. As soon as it is possible to mine minerals, beneficiate them and manufacture objects in outer space, then the development of space-science, access to and the use of space will bloom. This would benefit the space tourist industry, among other areas of space endeavour.

The last thing to mention here is that the type of structure needed for a space hotel would have to be large. It would need to be much larger than the current facilities available on the international space station and more massive than anything (man-made) floating around in outer space at the moment. The technology referred to above, in particular 3D printing and robotic construction, would allow for creating a hotel with meaningfully sized floor/wall/ceiling space (cubed space) that would give a bit of elbow room. This would also a) make it more of a viable idea for people (tourists amongst others) to visit such facilities, and b) once again have a beneficial knock-on effect. People would demand large, stateroom type cabins and living areas, which would in turn encourage the need for mining and engineering facilities in outer space. One should also not forget about the technological innovation that would be needed to build the massive, new type of space ship that would be able to transport colonists/adventurers/tourists/miners and others to other planets and possibly to the stars. Such a spacecraft could not be constructed on Earth in the near future, but could be constructed in outer space, using material mined and manufactured in outer space, without the gravitational and atmospheric constraints encountered on the Earth's surface. Such a vehicle would probably be designed and engineered not to deal with the stress of launching from a planet or descending down to it as it would launch from space. Such a ship would spend its complete operational lifetime in outer space and therefore would not need to be over engineered to as exacting specifications as our current space (launch and re-entry) vehicles, thus avoiding the exorbitant associated costs. 


\section{Property rights, ownership - or the lack thereof - in space}

Following on from the discussion in the preceding section, it is clear that innovation and investment in space is expensive and that whoever does invest in these enterprises will need protection of their investment in addition to some kind of reward. This is where property law comes in.

Referring to Bentham ${ }^{98}$ and Locke, ${ }^{99}$ Rose $^{100}$ underlines the essential argument for the protection of property interests.

... [P]eople will not work much without some inducement, and if there is no such inducement to labor, resources lie undeveloped and total wealth remains low. What induces people to labor? Property does. Let people have secure property, and they will learn to invest their labor on the things that they own, because they themselves will take the rewards. ... Once able to trade, they will invest even more in socially useful activities, because the whole world becomes the market for their efforts. ${ }^{101}$

Therefore, in space as on Earth, ${ }^{102}$ inducement to labour on new initiatives that could benefit society in general will depend on rights associated with property. If such rights are not allocated, then people are not induced to labour, and no initiatives will be undertaken to research and participate in space-related initiatives. Effectively the resources in outer space will lie fallow, with the resultant effect that any possible benefits (financial, technological and societal) will be lost.

Let us give the fledgling industries of space mining and tourism the benefit of the doubt and look fifteen years into the future. Having spent billions of dollars on the development of the technology and actually getting to the asteroid, or by that stage the Moon/Mars/Europa and wanting to start extracting the minerals or operating a tourist destination - how will we explain their legal status? ${ }^{103}$ What are their needs (from a legal perspective) to justify and protect the capital investment that they had to make to get there ? $^{104}$ What happens if they start mining an asteroid and a

98 Bentham "Principles of the Civil Code".

99 Laslett Locke: Two Treatises of Government.

100 Rose 1996 Notre Dame L Rev 330.

101 Rose 1996 Notre Dame L Rev 330-331.

102 Giving a new meaning to the concept of "as above, so below".

103 Also see the discussion above of the problems associated with the uncertainty of colonies and the possible founding of new nation states.

104 This question is essentially related to one of the most fundamental aspects of property law. If one were to embrace the post-political theory of property (law), where property rights are protected by organised government/political agreement, then one would need to have clearly defined protectable property rights/interests that one could count on being protected by society at large. This is also often referred to as the "bottom up" versus "top down" argument, in this context the post-political 
competitor starts mining on the same asteroid but on a different site, possibly negating the cost/benefit of the original mission? What happens if the planned orbital slot ${ }^{105}$ allocated to a space hotel is doled out to a mala fide competitor? And of course, who gives these companies the "right" to mine, or to open hotels in space, since (for the purposes of this argument) we acknowledge that ownership is not possible.

Why then do we want to talk about property rights, and especially about "ownership"? Why use the word "appropriate"? And why do we choose to draw a line in the sand and say ownership or nothing? Without going into too much detail, it boils down to the fact that it is better to have a right that has an erga omnes ${ }^{106}$ application and that can be enforced against third parties. In other words, having a property right or at the very least a right that provides property-like protection is better than having any other right to an object in space. ${ }^{107}$ Some brief illumination here will be in order.

Property rights to an object (and ownership in particular) will almost always ${ }^{108}$ be the preferred right that any person will want. The reason for this is a fundamental one. Ownership, of all the rights available, is still considered to be the most comprehensive of all rights; even if it is mostly not considered to be as absolute a right as was once argued. ${ }^{109}$ Still, much

theory is the same as the top-down approach. See Rose 1996 Notre Dame L Rev 335 , where she notes that "Locke's top-down story of property (like his bottom-up story) was related to the soon-to-be-standard economic argument that the security of property enhances total social wealth." This is quite clearly illustrated in how protecting property (rights) in space will lead to increased social wealth.

105 Orbital slots are currently managed by the International Telecommunication Union (ITU).

106 This relates to the principle of absoluteness and entails "... that a real right provides absolute certainty to the holder of that right with regard to the following aspects. The first aspect is that the holder's control over the property will be respected and protected. The second aspect is that the holder's right to the property will in general be given preference over other rights that third parties may have vested in the same property. The idea is to place the holder of a real right in an incontestable position vis-à-vis the property itself, as a consequence of which the holder's real right can be enforced against the whole world (erga omnes)", Erlank Property in Virtual Worlds 315. For more detail see Du Bois Wille's Principles of South African Law 410; Van der Merwe and De Waal Law of Things 7; Bauer, Bauer and Stürner Sachenrecht 29; Van der Merwe Sakereg 12.

107 See in general Erlank Property in Virtual Worlds iii, 112-117, 316, 374-376, 394-395.

108 Exceptions will usually pertain to when there are responsibilities (such as the payment of taxes) that are attached to ownership. In such a case, if someone could use an object and exploit it effectively without being the owner and without being liable for taxes (or other ownership related obligations), then ownership would not be the most desirable right to an object.

109 Book 2 Chapter 1 of Blackstone Commentaries. For a South-African/Roman-Dutch perspective see Visser 1985 Acta Juridica 47. 
like a curve that approaches a vertical line, ${ }^{110}$ neither the curve nor ownership will ever become absolute (in terms of ownership), or reach the vertical line (asymptote). There will always be some form of limitation to what one can do to or with one's property. Most of these limitations are imposed by society through custom, law or governance. ${ }^{111}$ However, in space the limiting influence of society will be much less significant than on Earth, while other limitations will be more predominant, with physical constraints being the most limiting. ${ }^{112}$ Still, ownership is considered to be the right that gives one the most comprehensive set of rights ${ }^{113}$ to an object, and this will always be the first prize. Second will be other less comprehensive property rights - usually framed in terms of providing someone with a limited (property) ${ }^{114}$ right to the property of someone else. ${ }^{115}$ Last in line (at least in terms of property and objects of property) are rights that one acquires from contract. In effect, in a competition between property rights and contractual rights, property rights will always be stronger and contractual rights will be weaker. The reason for this is that property rights are accorded a higher importance by society and an owner thus benefits from so-called third party protection (the erga omnes principle), while contractual rights apply only between the parties to the contract, and do not extend to third parties.

Another way to explain this is to say that while property rights protect or provide legal remedies to a person by focussing on the object itself, contractual rights provide other remedies, usually in the form of delictual claims. ${ }^{116}$ However, as with all rules, there are exceptions. In this case

110 Vertical asymptote.

111 For example, in terms of owning a motor vehicle one is limited to how fast one may drive one's motor vehicle, where one may drive it and how one should drive it, as well as being liable for the payment of taxes and licence fees amongst other things. In terms of neighbour law, one is also constrained by reasonableness not to cause a noise nuisance by "revving" the vehicle in one's property in the middle of the night.

112 If you are the only company able to get to and mine an asteroid, then you will not be concerned with someone else also acquiring the right to mine the asteroid. le, other competitors or third parties physically cannot infringe on your right to mine.

113 These rights are sometimes referred to as "competencies" that relate to an object.

114 Or "real" right.

115 Depending on the legal system, these can be referred to as limited real rights, servitudes and easements, amongst others.

116 An emotive example here is where someone sells you a dog, but six months later steals your dog and sells the dog to a third party. A property right will entitle you to claim back your dog from anyone who has it (even a third party acting in good faith) and you can depend on this right to your benefit against anyone in the world (whether they knew you were the owner or not - thus the third party effect). If you had only a contractual right to use the dog - let us say for the purpose of securing your business - then you would not be able to claim back the dog, but only some form of monetary compensation for breach of contract. If you have grown attached to 
there are certain contractual rights that should be weak but are almost as strong as property rights. These are referred to as property-like rights, or rights with property-like protection. ${ }^{117}$ In other words, while the rights are dependent on and derived from a contractual relationship between two contracting parties, and while ownership never passes in terms of this contract, the contractual right is imbued with strong property-like aspects. In most cases, this is derived from legislative protection that provides erga omnes application to the contract. Depending on the legislation, this gives the person using the object pretty much the same competencies towards the object that a property right would have had, and as such, for the purposes of using/exploiting the object, there is effectively no difference between being the owner of the object and not being the owner.

When applying these different alternatives to ownership and other property rights discussed above, the intrepid celestial entrepreneurs (whether pioneers, colonists, tourists, tourism operators or manufacturers) can therefore still have some sort of property right, or even a property-like protection ${ }^{118}$ of their interests in space. Some examples that come to mind include concessions, ${ }^{119}$ mining licences, prospecting rights, and certain contractual rights that could benefit from property-like protection. ${ }^{120}$ These rights could be derived from legislation that creates rights with propertylike protection. It could even be possible that a company would be quite happy with purely contractual rights - at least while there are no infringements of the rights and limited access to space is acting as some sort of protective mechanism for current endeavours. In all of these cases

the dog, then of course you will want the dog (the specific object) back, rather than the money. it is the fact that you have a property right that gives you this privilege.

117 See in general Erlank Property in Virtual Worlds iii, 112-117, 316, 374-376, 394-395.

118 Van der Walt 2004 SAPR/PL 258-261.

119 Many of these rights are often included under the name of so-called "new property rights" or socio-economic rights. See Reich 1964 Yale LJ 733-737; Van der Walt 2004 SAPR/PL 258-261.

120 For example, the relationship between a bank and a client is contractual, and the client in theory has only a weak contractual right against the bank in terms of having to perform by giving back the money in a client's account. This creates a problematic situation when a bank goes bankrupt. In such a case each client has only a concurrent (weak) claim to the amount that the bank owes the client in terms of the bank account. In effect this will mean that in a case of bankruptcy, the client will most certainly get back only a fraction of his or her money if the weak contractual relationship between the bank and the client is not strengthened. Therefore, some jurisdictions such as Australia and the Netherlands have enacted legislation that guarantees the repayment of money in the bank-client's account (up to a certain limit). In this example the legislation overrides the weak personal right to a concurrent claim and creates a stronger property-like right to the money. This means that the client's claim against the bank will be paid out first in the case of bankruptcy, and if there are not enough funds available from the bank, the government will pay the rest. In essence, this is the quintessential right with property-like protection. See De Nederlandsche Bank date unknown http://bit.ly/1Ofusm2. 
a socially or societally acceptable contract is made between the company and whoever the "trust"121 authority will be on Earth, a) to provide Planetary Resources/DSI with permission to mine, and b) to give them some sort of right to exclude others from their area of operation. ${ }^{122}$ In terms of space tourism, this trust authority will be responsible for the allocation of an orbital slot or allowing the construction and operation of a hotel on the Moon.

\section{Conclusion}

Having considered the issues relating to the development and needs of space-focussed operations such as tourism and mining, it seems that while the initial argument was that ownership is needed to protect a company's investment in its enterprise, what is actually needed is the ability to recoup the investment in some way - and for this ability to be protected. This is achieved by the ability to exclude others from interfering in your operation to your detriment. This could still happen if one does not use the concept of ownership but uses concepts such as licences and concessions, in other words, if property-like protection is not accorded to the rights that companies have to mine the asteroids or operate hotels. I will not go into the question of the extremely odd view that people who stay on earth, or governments, or some central authority could effectively prohibit someone from acquiring ownership in space or in a celestial object in space even if those people or that government or authority had no means of interfering with the actual object in space. At the end of the day, the question can be asked ... if no-one is there to interfere with the way in which you use something, does ownership have any meaning? If there are

121 Making use of the public trust "benefit of all mankind" language. Since we are ruling out ownership even for a governing authority, then one would need some sort of authority to manage the use of celestial real estate. Whether this authority will be UN-based or some alternative from the private sector is uncertain. What is certain is that someone will have to act as custodian of the resources and thus provide and manage the necessary rights to objects in space.

122 To a certain extent this follows the model of a commons - where the outer space resource is deemed to be a commons and the "rights" to make use of or exploit such commons are allocated according to the commons model. However, one needs only to look at the vehemently and diametrically opposed opinions in property law to see that the usefulness and management of such a system of commons can and does create many problems, and often leads to unintended consequences that in space would have the opposite effect of current space law treaties and agreements. For arguments for making use of a commons in general, see Rose 1986 U Chi L Rev. For arguments against this, see Hardin 1968 Science. For a more space-centric discussion focusing on how the proliferation of space debris is an example of the negative aspects of commons in space, see Wang $2013 \mathrm{http} / / / \mathrm{bit} . l \mathrm{ly} / 24 \mathrm{LNIvB}$. 
no sanctions to be applied if you use an object as if you are the owner, does the prohibition of calling yourself an owner have any effect? ${ }^{123}$

Let us also consider for a moment the possible sanctions that could be imposed on a company which operates in space as if it is the owner of celestial real estate. Who is able to prevent you from doing something or infringe on your possession? The nature of the location creates a technically environmentally enforced exclusion of others to the benefit of the user. When there is no one to stop a company from doing something, one possible way of trying to punish it will be by imposing sanctions against the purchase of its products. This is of course not an uncircumventable problem, as companies tend to find markets for their products even in the face of sanctions. Inertial drives and anti-gravity will change the raison d'être for mining in space, but not necessarily soon enough. Even if sanctions against the purchase of space-obtained materials are put into place, then the miners will still have a de facto monopoly that will sustain their operations. This will be so especially when the mining in outer space does not presuppose that the minerals need to be brought back down to the surface of the Earth. The benefit of mining natural resources in outer space will be in the ability to manufacture massive spacecraft and space stations in the weightless environment of outer space. This ability is extremely important for future developments in man's access to and use of space, since firstly it is prohibitively expensive to transport natural resources from the surface of the Earth into outer space $^{124}$ and secondly, one will not be constrained by the physical limitations placed on the construction of spacecraft on the ground. ${ }^{125}$

Alternatively, the imprisonment/sequestration/winding up of the holding company on Earth and possibly military action could act as a deterrent. The problem is that if private companies are so powerful as to be able to spend the required money on getting to space, exploiting the celestial environment and effectively bringing the much needed minerals back to earth, and not necessarily down to earth, they may also have the political as well as the technological and military means to defend their factual position regarding the celestial property, even though there is a prohibition on the placement of weapons in outer space. ${ }^{126}$ In other words, if we will

123 Also see Erlank $2012 \mathrm{http}: / /$ bit.ly/24J1GhO for wanting/needing to exclude in order to protect. Also see Erlank 2015 PELJ.

124 See above for a discussion of costs.

125 To circumvent this problem such engineering feats (still theoretical) as space lifts and inertial drives have been proposed.

126 Treaty on the Prevention of the Placement of Weapons in Outer Space, the Threat or Use of Force against Outer Space Objects (2008). 
not provide them with a legal means of exclusion, however vague that might be, from Earth, they will provide it for themselves. The same goes for colonists in outer space. How will we prevent them from exercising the right to self-determination to found a new sovereign nation on a celestial body?

In my previous analysis ${ }^{127}$ of ownership in space, I noted the temporary aspect of granting current ownership of a celestial body or part thereof, the temporary aspects being associated with the ability to exercise possession as well as effective control ${ }^{128}$ over the celestial real estate. So, however we use the word ownership, ownership effectively ends with the loss of possession or effective control over the real estate in space. ${ }^{129}$ This is then not very different from giving someone a concession or a licence to mine the celestial real estate and leave it again when he is finished. What is the difference between the ownership, then, and the concession; or ownership and possession for that matter? The company has achieved the same goals and we are not infringing on any international conventions.

Hence we have managed to achieve exactly the same goal as we set out to achieve in the beginning - to justify ownership in space, which has exactly the same consequences. While we have not used the word ownership, the important rights and competencies that people will need to protect their property or business interests in space can also in most instances be acquired from other forms of property rights, or even property-like contractual rights, essentially thus moving the goalposts so that the players don't notice.

\section{Bibliography}

\section{Literature}

Bauer, Bauer and Stürner Sachenrecht

Bauer F, Bauer JF and Stürner R Sachenrecht $17^{\text {th }}$ ed $(\mathrm{CH}$ Beck München 1999)

Bentham "Principles of the Civil Code"

Bentham $\mathrm{J}$ "Principles of the Civil Code" in Bowring $\mathrm{J}(\mathrm{ed})$ The Works of Jeremy Bentham Vol I (William Tait Edinburgh 1864) 297-364

127 Erlank 2012 http://bit.ly/24J1GhO; Erlank 2015 PELJ.

128 Meaning that before we can allocate property to someone in space, they have to get there, stay there and exert effective control over the property. The size of the possession/use/ownership of the property will also be limited to a certain area that a person or company can effectively control of make beneficial use of. See Erlank 2012 http://bit.ly/24J1GhO; Erlank 2015 PELJ. 
Blackstone Commentaries

Blackstone W Commentaries on the Laws of England (Clarendon Oxford 1765-1769)

Blount 2011 Denv J Int'l L \& Pol'y

Blount PJ "Renovating Space: The Future of International Space Law" 2011 Denv J Int'l L \& Pol'y 515-532

Chatzipanagiotis 2011 Proceedings of the IISL

Chatzipanagiotis M "The Impact of Liability Rules on the Development of Private Commercial Human Spaceflight" 2011 Proceedings of the IISL 5262

Cherian and Abraham 2007 JICLT

Cherian GJ and Abraham J "Concept of Private Property in Space - An Analysis" 2007 JICLT 211-220

Diederiks-Verschoor Introduction to Space Law

Diederiks-Verschoor IHP An Introduction to Space Law $3^{\text {rd }}$ ed (Kluwer Law Alphen aan den Rijn 1999)

Du Bois Wille's Principles of South African Law

Du Bois F (ed) Wille's Principles of South African Law $9^{\text {th }}$ ed (Juta Cape Town 2007)

Elvis 2014 Planetary and Space Science

Elvis M "How Many Ore-bearing Asteroids?" 2014 Planetary and Space Science 20-26

Erlank Property in Virtual Worlds

Erlank W Property in Virtual Worlds (LLD-dissertation University of Stellenbosch 2012)

Erlank 2015 PELJ

Erlank W "Rethinking Terra Nullius and Property Law in Space" 2015(4) PELJ 1-24

Erlank 2016 (forthcoming)

Erlank W "Classifying Objects in Space According to South African Law" 2016 (forthcoming)

Ferreira-Snyman 2014 PELJ

Ferreira-Snyman A "Legal Challenges Relating to the Commercial Use of Outer Space, with Specific Reference to Space Tourism" 2014 PELJ 2-50 
Freeland 2010 Melb J Int'l L

Freeland S "Fly Me to the Moon: How will International Law Cope with Commercial Space Tourism?" 2010 Melb J Int'l L 90-118.

Freeland "Outer Space and the Non-Appropriation Principle"

Freeland S "Outer Space and the Non-Appropriation Principle" in Smith JC (ed) Property and Sovereignty (Ashgate Surrey 2013) 81-98

Goh Dispute Settlement

Goh GM Dispute Settlement in International Space Law (PhD-dissertation University of Leiden 2007)

Hardin 1968 Science

Hardin G "The Tragedy if the Commons" 1968 Science 1243-1248

Hasnain, Lamb and Ross 2012 Acta Astronautica

Hasnain Z, Lamb CA and Ross SD "Capturing Near-Earth Asteroids around Earth" 2012 Acta Astronautica 523-531

Heinlein Friday

Heinlein RA Friday (Del Rey New York 1983)

Hobe 2007 Neb L Rev

Hobe S "Legal Aspects of Space Tourism" 2007 Neb L Rev 439-458

Hobe and Cloppenburg 2004 Proceedings of the IISL

Hobe S and Cloppenburg J "Toward a New Aerospace Convention? Selected Legal Issues of 'Space Tourism'" 2004 Proceedings of the IISL 377-383

Hoffstadt 1994 UCLA L Rev

Hoffstadt BM "Moving the Heavens: Lunar Mining and the 'Common Heritage of Mankind' in the Moon Treaty" 1994 UCLA L Rev 575-621

Laslett Locke: Two Treatises of Government

Laslett P Locke: Two Treatises of Government (Cambridge University Press Cambridge 1988)

Listner 2003 Regent J Int'l L

Listner MJ "The Ownership and Exploitation of Outer Space: A Look at the Foundational Law and Future Legal Challenges to Current Claims" 2003 Regent J Int'l L 75-94

Lyall and Larsen Space Law Lyall F and Larsen PB Space Law: A Treatise (Ashgate Surrey 2009) 
Marks NewScientist

Marks P "Who Owns Asteroids or the Moon?" NewScientist (2 June 2012) 28

Masson-Zwaan 2008 Proceedings of the IISL

Masson-Zwaan T "Article VI of the Outer Space Treaty and Private Human Access to Space" 2008 Proceedings of the IISL 536-546

Neger and Walter "Space Law"

Neger T and Walter E "Space Law: An Independent Branch of the Legal System" in Brünner C and Soucek A (eds) Outer Space in Society, Politics and Law (Springer Vienna 2011) 234-246

O'Leary 1988 Acta Astronautica

O'Leary B "Asteroid Mining and the Moons of Mars" 1988 Acta Astronautica 457-462

Preston and Child Wheel of Darkness

Preston D and Child L The Wheel of Darkness (Hachette New York 2008)

Radin Reinterpreting Property

Radin MJ Reinterpreting Property (University of Chicago Press Chicago 1993)

Reich 1964 Yale LJ

Reich C "The New Property" 1964 Yale LJ 733-787

Rose 1986 U Chi L Rev

Rose CM "The Comedy of the Commons: Customs, Commerce, and Inherently Public Property" 1986 U Chi L Rev 711-781

Rose 1996 Notre Dame L Rev

Rose CM "Property as the Keystone Right?" 1996 Notre Dame L Rev 329369

Sippel 2010 Acta Astronautica

Sippel M "Promising Roadmap Alternatives for the SpaceLiner" 2010 Acta Astronautica 1652-1658

Sonter 1998 Acta Astronautica

Sonter MJ "The Technical and Economic Feasibility of Mining the NearEarth Asteroids" 1998 Acta Astronautica 637-647

Sundahl 2009 J Space L

Sundahl MJ "The Duty to Rescue Space Tourists and Return Private Spacecraft" 2009 J Space L 163-200 
Twibell 1997 ILSA J Int'I \& Comp L

Twibell TS "Circumnavigating International Space Law" 1997 ILSA J Int'l \& Comp L 259-295

Van der Merwe Sakereg

Van der Merwe CG Sakereg $2^{\text {nd }}$ ed (Butterworths Durban 1989)

Van der Merwe and De Waal Law of Things

Van der Merwe CG and De Waal MJ The Law of Things and Servitudes (Butterworths Durban 1993)

Van der Walt 2004 SAPR/PL

Van der Walt "A South African Reading of Frank Michelman's Theory of Social Justice" 2004 SAPR/PL 253-307

Van Wyk 2008 African Skies

Van Wyk JA "Overview of the Implementation Status of the Five United Nations Treaties on Outer Space in African Countries" 2008 African Skies / Cieux Africains 90-99

Visser 1985 Acta Juridica

Visser D "The 'Absoluteness' of Ownership: The South African Common Law in Perspective" 1985 Acta Juridica 39-52

Walter "Privatisation and Commercialisation of Outer Space"

Walter E "The Privatisation and Commercialisation of Outer Space" in Brünner C and Soucek A (eds) Outer Space in Society, Politics and Law (Springer Vienna 2011) 493-518

\section{International instruments}

Agreement Governing the Activities of States on the Moon and Other Celestial Bodies (1979) (Moon Agreement)

Agreement on the Rescue of Astronauts, the Return of Astronauts and the Return of Objects Launched into Outer Space (1968) (Rescue Agreement) Convention on International Liability for Damage Caused by Space Objects (1972) (Liability Convention)

Convention on Registration of Objects Launched into Outer Space (1975) (Registration Convention)

Treaty on Principles Governing the Activities of States in the Exploration and Use of Outer Space, including the Moon and Other Celestial Bodies (1967) (Outer Space Treaty) 
Treaty on the Prevention of the Placement of Weapons in Outer Space, the Threat or Use of Force against Outer Space Objects (2008)

\section{Legislation}

US Commercial Space Launch Competitiveness Act HR 2262 of 2015

\section{Internet sources}

BBC News 2007 http://bbc.in/1XjQVAk

BBC News 2007 Russia Plants Flag Under N Pole http://bbc.in/1XjQVAk accessed 20 March 2015

Brewster 2013 http://bit.ly/1Tzlixb

Brewster S 2013 NASA Wants to Build Huge Spacecraft in Orbit with Robots and 3D Printers http://bit.ly/1Tzlixb accessed 25 March 2015

De Nederlandsche Bank date unknown http://bit.ly/1Ofusm2

De Nederlandsche Bank date unknown Deposit Guarantee Scheme http://bit.ly/1Ofusm2 accessed 23 March 2015

DSI date unknown http://bit.ly/24LnJld

Deep Space Industries date unknown NASA Postpones Decision on Asteroid Redirect Mission Strategy http://bit.ly/24LnJld accessed 20 March 2015

DSI 2015 http://bit.ly/1XjRmdT

Deep Space Industries 2015 Deep Space Industries: Building the Infrastructure of a New Space Economy http://bit.ly/1XjRmdT accessed 20 March 2015

Dezeen 2013 http://bit.ly/1T9zfV6

Dezeen 2013 NASA Develops 3D Printing Factory in Space http://bit.ly/1T9zfV6 accessed 26 March 2015

Dilorenzo and Hinnant 2013 http://yhoo.it/1XjRWZi

Dilorenzo S and Hinnant L 2013 Supersonic Travel? Ballistic Jetliners? Air Travel Innovations are Slower, Subtler http://yhoo.it/1XjRWZi accessed 15 March 2015

Erlank $2012 \mathrm{http}: / /$ bit.ly/24J1GhO

Erlank W 2012 Rethinking Terra Nullius and Property Law in Space http://bit.ly/24J1GhO accessed 15 March 2015

ESA 2013 http://bit.ly/1rEZMjS

European Space Agency 2013 Building a Lunar Base with 3D Printing http://bit.ly/1rEZMjS accessed 26 March 2015 
ESA 2015 http://bit.ly/1VSd0GN

European Space Agency 2015 ESA Science Rosetta http://bit.ly/1VSd0GN accessed 20 March 2015

Foster and Partners 2013 http://bit.ly/1WYY8Fp

Foster and Partners 2013 Foster + Partners Works with European Space Agency to 3D Print Structures on the Moon http://bit.ly/1WYY8Fp accessed 27 March 2015

Fuentes 2015 http://bit.ly/1OfvM8x

Fuentes U 2015 Understanding the Legal Status of the Moon http://bit.ly/1OfvM8x accessed 5 March 2015

Futron 2002 httpwasser:/www.futron.com/upload/wysiwyg/Resources/ Whitepapers/Space_Transportation_Costs_Trends_0902.pdf

Futron 2002 Transportation Costs: Trends in Price per Pound to Orbit 1990-2000

http://www.futron.com/upload/wysiwyg/Resources/Whitepapers/Space_Tr

ansportation_Costs_Trends_0902.pdf accessed 30 March 2015

Hartnett 2014 http://bit.ly/2dUGd3u

Hartnett K 2014 The Comet Landing as a Prelude to Asteroid Mining http://bit.ly/2dUGd3u accessed 26 March 2015

Komnenic 2014 http://bit.ly/1ZCi7ch

Komnenic A 2014 Is Space Mining Commercially Viable? http://bit.ly/1ZCi7ch accessed 16 March 2015

Lewis 1984 http://nyti.ms/1WmzfEz

Lewis P 1984 Europe's Factories in Space http://nyti.ms/1WmzfEz accessed 26 March 2015

Listner 2011 http://bit.ly/21TTN7n

Listner MJ 2011The Moon Treaty: Failed International Law or Waiting in the Shadows? http://bit.ly/21TTN7n accessed 5 March 2015

Mars Initiative 2015 http://www.marsinitiative.org

Mars Initiative 2015 Mars Initiative http://www.marsinitiative.org accessed 28 March 2015

Mars One 2015 http://www.mars-one.com

Mars One 2015 Mars One http://www.mars-one.com accessed 28 March 2015 
NASA JPL date unknown http://go.nasa.gov/27dZXDo

National Aeronautics and Space Administration Jet Propulsion Laboratory date unknown Rosetta Overview http://go.nasa.gov/27dZXDo accessed 20 March 2015

Orzel 2011 http://bit.ly/1qdZTlb

Orzel C 2011 Ballistic Air Travel Uncertain Principles http://bit.ly/1qdZTIb accessed 30 March 2015

Planet Science $2012 \mathrm{http}: / / \mathrm{bit}$. ly/23HPDyK

Planet Science 2012 Mining in Space http://bit.ly/23HPDyK accessed 27 March 2015

Planetary Resources 2014 http://bit.ly/1sdM2gT

Planetary Resources 2014 Recap of a Memorable Year from Planetary Resources http://bit.ly/1sdM2gT accessed 30 March 2015

Reynolds $2008 \mathrm{http}: / / \mathrm{bit} . l y / 1$ qe0VO5

Reynolds GH 2008 Who Owns the Moon? The Case for Lunar Property Rights http://bit.ly/1qe0VO5 accessed 5 March 2015

Risen 2014 http://bit.ly/21X2gqA

Risen T 2014 Rosetta Comet Landing is Space Game-Changer http://bit.ly/21X2gqA accessed 20 March 2015

Thomas 2013 http://reut.rs/1XIrAGj

Thomas S 2013 Gold Rush in Space? Asteroid Miners Prepare, But Eye Water First http://reut.rs/1XIrAGj accessed 26 March 2015

Wang $2013 \mathrm{http}: / /$ bit.ly/24LNIvB

Wang P 2013 Tragedy of Commons in Outer Space: The Case of Space Debris http://bit.ly/24LNIvB accessed 26 March 2015

Wikipedia Contributors 2015 http://bit.ly/24OtSTS

Wikipedia Contributors 2015 Spaceflight: Point to Point Sub Orbital Spaceflight http://bit.ly/24OtSTS accessed 20 March 2015

\section{List of Abbreviations}

DSI

Denv J Int'I L \& Pol'y

ESA

GTO

ICBM
Deep Space Industries

Denver Journal of International Law and Policy

European Space Agency

Geostationary Transfer Orbit

Intercontinental ballistic missile 


\begin{tabular}{|c|c|}
\hline ILSA J Int'I \& Comp L & $\begin{array}{l}\text { ILSA Journal of International and Comparative } \\
\text { Law }\end{array}$ \\
\hline ISS & International Space Station \\
\hline ITU & International Telecommunication Union \\
\hline J Space L & Journal of Space Law \\
\hline JICLT & $\begin{array}{l}\text { Journal of International Commercial Law and } \\
\text { Technology }\end{array}$ \\
\hline LEO & Low Earth Orbit \\
\hline Melb J Int'I L & Melbourne Journal of International Law \\
\hline NASA JPL & National Aeronautics and Space \\
\hline & Administration Jet Propulsion Laboratory \\
\hline Neb L Rev & Nebraska Law Review \\
\hline Notre Dame L Rev & Notre Dame Law Review \\
\hline PELJ & Potchefstroom Electronic Law Journal \\
\hline Proceedings of the IISL & $\begin{array}{l}\text { Proceedings of the International Institute of } \\
\text { Space Law }\end{array}$ \\
\hline Regent J Int'I L & Regent Journal of International Law \\
\hline SAPR/PL & $\begin{array}{l}\text { Suid-Afrikaanse Publiekreg / South African } \\
\text { Public Law }\end{array}$ \\
\hline TUI & Tethers Unlimited Inc \\
\hline U Chi L Rev & University of Chicago Law Review \\
\hline UCLA L Rev & $\begin{array}{l}\text { University of California at Los Angeles Law } \\
\text { Review }\end{array}$ \\
\hline UNCOPUOS & $\begin{array}{l}\text { United Nations Committee on the Peaceful } \\
\text { Uses of Outer Space }\end{array}$ \\
\hline Yale LJ & Yale Law Journal \\
\hline
\end{tabular}

